DOI: $10.1515 /$ hssr -2017-0017

HSS VI.2 (2017)

\title{
The Foreign Languages Factor in the Development of Tourism in Nigeria
}

\author{
Mike T. U. Edung* \\ University of Uyo, Nigeria
}

\begin{abstract}
Inbound tourism as defined by the WTO is obviously the aspect of a nation's tourism industry to which foreign languages are directly relevant: this aspect involves foreign tourists visiting the country of reference. This paper uses Leiper's (1979) conceptualisation of the tourism system to examine the role of foreign languages in the operations of Nigerian inbound tourism from TGR and TDR perspectives. Among the most significant revelations of this examination are the facts that: i) tourism destinations in Nigeria are to be advertised on the web and in print in the TGR countries using the languages of those countries; and ii) tour guides in Nigeria are to be trained in foreign languages to facilitate travels, stay and related transactions and activities of foreign tourists in Nigeria. These and other findings can enhance the Nigerian inbound tourism industry.
\end{abstract}

Keywords

Inbound tourism, Foreign languages, Tourists generating regions, Tourism, Destination region, Nigerian tourism destinations.

\section{Introduction}

Motivated by the expected gains from a developed tourism industry in Nigeria, as articulated over the years, and the desire to contribute their quota to such a development, numerous studies have identified and

\footnotetext{
* Department of Foreign Languages, University of Uyo, Ipka Rd Nigeria; email : udoedung@yahoo.com
} 
examined various issues and factors that can hasten this development. It is in this context that this study examines the place of foreign languages in the development of tourism in Nigeria. We are concerned here with the aspect of tourism known as inbound tourism, to which foreign languages are clearly and directly relevant. An attempt shall be made to establish the specific ways in which foreign languages bear relevance to this aspect of tourism.

The paper begins by specifying the foreign languages in the Nigerian context. It proceeds to examine the present-day concept and practice of tourism with a view to identifying the aspects of its operations in which foreign languages have their relevance and which is inbound tourism. Using Leiper's (1979) conceptualisation of tourism system as our analytical framework, the paper examines the operations of Nigeria's inbound tourism with a view to showing the role which foreign languages can play in enhancing such operations.

\section{Foreign Languages in the Nigerian Context}

The literature on "foreign languages" has presented three types of definitions of a foreign language: the geo-political, the linguistic, and the sociolinguistic definitions. The first two were clearly presented by Alisah (2005), while the third was presented by this writer in Edung (2001), following Wilkins (1972: 153) and Crystal (1997: 362). Of these three definitions, the geo-political and the sociolinguistic ones are pertinent to our present study. As we shall soon see, the sociolinguistic definition has shown quite practically, the languages which are appropriately "foreign" to Nigeria, avoiding the weakness of the geo-political definition, by which English is generally but erroneously classified as a foreign language in Nigeria, a classification that brings much confusion in issues such as the subject matter of this study.

Giving the geo-political definition of a foreign language, Alisah (2005) submits that

A language is considered "foreign" to a particular country when the natural habitat of its native speakers is nowhere to be located within its borders. In other words, the existing home of the language is to be found outside the country. For example, Ki-Swahili, Wolof, English, French, Arabic, Spanish, 
Portuguese, etc., are all foreign languages in Nigeria because their native homes are located outside its borders.

From the perspective of sociolinguistics, the science which studies the place and functions of language and languages in society,

a foreign language in a given country is a language which is not the mother tongue of any indigenous community in the country and has no internal communication function in such a country, its learning and use within the country only serving to ease contact with non-indigenes. The foreign languages in Nigeria will therefore include all non-African languages except English, as well as all African languages which are not indigenous to Nigeria (Edung 2001:4).

Alisah has eloquently demonstrated the problem of the geo-political definition of foreign language with the case of the regions of Alsace and Lorraine, which had at different times in history been parts of France, and then of Germany, and then of France again where they have remained to date, with the consequence that the peoples of these regions speak both French and German from birth, making it difficult to say that German is as such a foreign language in these two regions of France, which the geo-political definition makes it to be. Contrariwise, the sociolinguistic definition makes things rather straightforward with the internal communication criterion which makes German an indigenous language, just as French, in these regions of France, given the fact that the peoples of these regions communicate among themselves in any of these two languages.

The position of English in Nigeria becomes very clear with the sociolinguistic definition of foreign language. Though it is historically foreign to Nigeria, and its native speakers live outside the country's borders, English has internal communication function in Nigeria, given the facts that it is the language of official business in the country, and that it (or at least some form of it) is the medium in which Nigerians with different mother tongues generally communicate with one another. It is interesting to note that it is on the basis of this second function of the English language in Nigeria that Brann (1981) classified it, not only among the Nigerian endolects, i.e. the indigenous Nigerian languages, but 
as also belonging to a sub-class of the endolects, the sub-class of metalect, defined as "a link language" used for communication between Nigerians from different linguistic backgrounds. The point has also been made that the fact that there is today what is called Standard Nigerian English (SNE) or Educated Nigerian English (ENE) is strong evidence that English has been domesticated in Nigeria. Bamiro (1991) has been quoted by Adegbija (2004) to have remarked in this regard that

That an internal norm [which is what constitutes the SNE] has developed is evident from the fact that numerous structures that would be totally unintelligible to native speakers of English are officially used at the highest level of government in Nigeria.

English is therefore clearly not among the foreign languages envisaged in this study. It is now a generally accepted fact among scholars and the Nigerian elite that English has become a national language in Nigeria. (cf. Achebe (1975), Brann (1981), Adegbija (2004) and Alisah (2005), to mention only a few of these ones). In this study and generally therefore, foreign languages as far as Nigeria is concerned, are clearly the native languages of other countries, and they do not include English.

\section{Tourism: A Multidimensional and Multifaceted Activity}

\subsection{Defining Tourism}

For a fruitful examination of the subject matter of this paper, we must first of all have a clear view of tourism in its present-day conceptualisation and practice. Authorities in the study of tourism have generally acknowledged the difficulty of defining tourism as it is practised today. Giving the reason for this difficulty, Cooper et al. (2008:5) have reported the view of Gilbert (1990: 7) that

What makes tourism difficult to define is the very broad nature of the concept as well as the need for so many service inputs. Tourism ... envelops other sectors and industries ... and therefore has no clear boundary due to the expansive spread of activities it covers. 
Cooper et al. have themselves submitted in affirmation of the above view that "in reality, the tourism industry consists of a mass of organisations operating in different sectors each of which supplies those activities which are termed tourism" (Cooper et al, 2008:5). This is to say that a good number of the activities of many organisations in diverse sectors of the economy are also considered as tourism activities. The literature of tourism research has revealed that the concept of tourism has been a continuously expanding one. A number of studies such as Leiper (1979), Vanhove (2004), and Cooper et al. (2008), to mention but these three, have offered explanations for this continuously expanding concept of tourism, and to know them should be useful for this study.

Tourism research has shown that the early-day definitions of tourism were conceptual and holistic in nature, characteristically attempting to capture what was considered to be the essence of tourism. A typical example of a conceptual definition of tourism, and an often cited one was given in 1976 by the Tourism Society of Britain, which saw tourism as "the temporary, short-term movement of people to destinations outside the places where they normally live and work and their activities during their stay at these destinations" (cited by Chakraborty and Chakravarti, 2008: 5).

Tourism research has further revealed that as a productive economic activity, tourism has its products, both tangible and intangible, and therefore it has the demand and the supply sides. Nations, institutions and organisations interested in the study and measurement of the economic activities of nations and of the world also became interested in measuring the economic impact and value of tourism. To be scientific and accurate and therefore reliable, such measurements required precise definitions of the relevant elements of tourism. This means that tourism had to be analysed, and its component elements identified and then defined. This is what gave rise to the type of definitions known as operational or technical definitions of tourism, in contradistinction to conceptual definitions. One of the earliest technical definitions of tourism is generally said to have been given by the Committee of Statistical Experts of the League of Nations which in 1937 defined the tourist, an element in tourism, as "any person visiting a country, other than that in which he/she usually resides, for a period of at least 24 hours" 
(www.prm.nau.edu/PRM300/what-is-tourism-lesson.htm, Accessed on 05/06/2016).

Both the conceptual and the technical definitions have been evolving, and each approach, in its own way, has revealed tourism to be multidimensional and multifaceted. Conceptual definitions have led to the categorisation of tourism based on the defining elements of people travelling to destinations outside the places they normally live and work, their purpose for the travel, their activities during the travel and at their destinations. Later categorisations have been made on the basis of the ethos of tourism. Based on the geographical location of the destination people travel to, there is domestic and international tourism, and even space tourism has been envisaged in the near future. On the basis of the purpose of the travel, and this is closely linked to the travellers' activities before and at the destination, some forms or types of tourism have been identified including adventure tourism, agritourism, culinary tourism, educational tourism, health or medical tourism, religious tourism, sports tourism, wildlife tourism, wine tourism, among many other types of niche or special interest tourism. Still other types of tourism have emerged on an ethical basis, and these include what has come to be known as ecotourism, pro-poor tourism, sustainable tourism, etc. (cf. en.wikibooks.org/wiki/Introductory_Tourism (Accessed on 05/06/2016) and particularly Novelli (2005), to mention only these two sources).

On their part, technical definitions of tourism are worked out principally for the purpose of measuring the economic value of tourism, generally within the context of the economy of individual nations and of the world. This measurement is done mainly on the basis of the consumption by tourists or travellers within the country of reference. Technical definitions of tourism have thus emphasized the types or forms of tourism that make for the practical measurement of such consumption. It is on the basis of such consumption that tourism has been identified as domestic, inbound, outbound, internal, national and international tourism (cf. Cooper et al. (2008) and UNWTO (2010) in particular).

Whereas there is no consensus on the forms of tourism as identified in the conceptual approach to the definition of tourism, the forms 
identified in the technical approach are stable. This is so because they are the formulations of specialized institutions purposefully committed to specified goals in tourism. This has been so right from the 1937 definition of tourism by the Committee of Statistical Experts of the League of Nations, when this world organisation decided and began to apply the tool of statistics to scientifically study and measure world trends particularly in the economic domain. (cf. Frangialli, 2009). Today, the United Nations World Tourism Organisation (UNWTO), which has been working essentially with technical definitions of tourism, has published official definitions of tourism and of those forms of it on which the Organisation bases its studies. As already mentioned in the previous paragraph, these forms are domestic, inbound, outbound, internal, national and international tourism. In fact, the UNWTO document entitled Glossary of Tourism Terms and published online at https://s3-eu-west-1.amazonaws.com/staticunwto/Statistics/Glossary+ of+terms.pdf (last updated February, 2014), states in this regard that

There are three basic forms of tourism: domestic tourism, inbound tourism, and outbound tourism. These can be combined in various ways to derive the following additional forms of tourism: internal tourism, national tourism and international tourism.

These then are the forms of tourism that have officially agreed definitions, beside the officially agreed definition of tourism in general which has been given in the just mentioned UNWTO tourism glossary document as

a social, cultural and economic phenomenon which entails the movement of people to countries or places outside their usual environment for personal or business/professional purposes. These people are called visitors (which may be either tourists or excursionists; residents or non residents) and tourism has to do with their activities ...

It must be pointed out here that the terms written in italics in the UNTWO definition of tourism cited above are also defined in the glossary. Thus an excursionist, also called same-day visitor, is a visitor whose 
trip does not include an overnight stay, while a tourist, also called overnight visitor, is a visitor whose trip includes an overnight stay.

Even with the consensual definition of tourism given above by the UNWTO, the remark is very often made in the literature on tourism, by experts in the field, that there is no generally accepted definition of tourism, just as it is also generally remarked that it is difficult to get any such definition of it because of the clearly complex nature of tourism. From all indications then, studies and other forms of work on tourism tend to produce or adopt definitions that are suitable for their purpose. As we have earlier observed in this discussion, technical definitions of tourism have been produced by studies and works carried out from the perspective of tourism as an economic activity, as a factor in the economic development of a nation. This being the perspective of this study, we shall retain the UNTWO's technical definition of tourism which we cited in the last paragraph.

\subsection{The International Dimension of Tourism}

An examination of the role of foreign languages in the development of the tourism industry in any country naturally points to the international dimension of this industry. Dimensions or forms or types of tourism are identified based on different criteria. In the conceptual approach to tourism studies, international tourism and its opposite form, domestic tourism, are defined on the basis of the tourists' or visitors' country of residence. Writing in this approach in the introductory chapter of their monumental work, Tourism Principles and Practice, and specifically in the section entitled "Interrelationships and Classifications", Cooper et al. (2008: 15) tell us inter alia that "Domestic tourism refers to travel by residents within their country of residence. ... In contrast, international tourism involves travel outside the country of residence". The technical approach to definitions in tourism which we have seen above, conceives of international tourism differently. Concerned more with the measurement in statistical terms of the economic value of tourism activities based on the actual expenditure of tourists on tourism products (goods and services) in the transit and in the destination regions, we saw earlier that the technical definitions of tourism distinguish primarily between 
domestic, inbound, and outbound tourism, which "can be combined in various ways to derive ... internal tourism, national tourism and international tourism" (UNWTO, Glossary of Tourism Terms, 5). According to the UNWTO, "international tourism comprises inbound tourism and outbound tourism". We can now cite the UNWTO technical definitions of these concepts to clarify issues about the international dimension of tourism, especially as they would interest us in the Nigerian tourism industry.

Inbound tourism comprises the activities of a non-resident visitor within the country of reference on an inbound tourism trip.

Outbound tourism comprises the activities of a resident visitor outside the country of reference, either as part of an outbound tourism trip or as part of a domestic tourism trip.

International tourism comprises inbound and outbound tourism, that is to say, the activities of resident visitors outside the country of reference, either as part of domestic or outbound tourism trips and the activities of nonresident visitors within the country of reference on inbound tourism trips (UNWTO, Glossary of Tourism Terms, 5-7)

Two terms in the above formulations need to be defined for us to get a clearer view still of international tourism as it concerns the present study: these terms are country of reference and domestic tourism. "The country of reference refers to the country for which the measurement is done" (UNWTO Glossary of Tourism Terms: 2). The measurement in question here, we must recall, is the measurement of tourism consumption in the country of reference. Explaining the concept of tourism consumption, the UNWTO Glossary of Tourism Terms, says inter alia that

Besides the amount paid for the acquisition of consumption goods and services, as well as valuables for own use or to give away, for and during tourism trips, which corresponds to monetary transactions [...], it [i.e. tourism consumption] also includes services associated with vacation accommodation on own account, tourism social transfers in kind and other imputed consumption. These transactions need to be estimated using sources different from information collected directly from visitors, such as reports on home exchanges, estimations of rents associated with 
vacation homes, calculations of financial intermediation services indirectly measured (FISIM), etc.(....11).

Domestic tourism is technically defined by the UNTWO as comprising "the activities of a resident visitor within the country of reference, either as part of a domestic tourism trip or part of an outbound tourism trip". (UNWTO Glossary of Tourism Terms, 3).

Taking Nigeria as the country of reference, as it is in the present study, it is clear that tourism trips and consumption of Nigerian residents in Nigeria, even while they are on outbound tourism trips, are not part of Nigeria's international tourism but of irs domestic tourism. Certainly, the activities of Nigerian residents on tourism trips outside Nigeria, constitute part of global international tourism, but they are not part of Nigeria's international tourism, since Nigeria is not the country of reference. This means that the relevant tourism consumption on such trips is not measured in favour of the Nigerian economy. In terms of tourism consumption measurable and measured in favour of the Nigerian economy, and that is to say, in terms of what contributes to the development of the Nigerian economy, which is our point of interest in this study, Nigeria's international tourism consists therefore of the activities and the resultant tourism consumption of non-resident visitors within Nigeria. In technical terms, Nigeria's international tourism consists of inbound tourism. This aspect of international tourism which clearly involves foreign visitors or tourists in any given country of reference, obviously and logically gives foreign languages an important place in its operations.

\section{Nigeria's Inbound Tourism Operations and the Place of Foreign Languages}

\subsection{Framework of Analysis}

Having seen that inbound tourism brings foreign tourists into a country of reference, thus giving some place to foreign languages in its operations, our discussion shall now proceed to examine the place of foreign languages in the inbound tourism operations of Nigeria as the country of reference in this study. We have found it useful and practical 
to adopt Leiper's (1979) systems framework of tourism in this examination of the operations of Nigeria's inbound tourism.

An early advocate of the adoption of a systems approach to the understanding of tourism, and indeed a great influence on theory and practice in the field, Leiper posited that tourism is

...the system involving the discretionary travel and temporary stay of persons away from their usual place of residence for one or more nights, excepting tours made for the primary purpose of earning remuneration from points en route. The elements of the system are tourists, generating regions, transit routes, destination regions and a tourism sector. These five elements are arranged in spatial and functional connections. Having the characteristics of an open system, the organization of these five elements operates within broader environments: physical, cultural, economic, political, technological with which it interacts. (Leiper 1979; our emphasis).

As the above formulation can show, the tourism system as conceptualised by Leiper, consists of five elements: 1) the tourists; 2) the tourists' generating regions (TGR); 3) the tourism transit routes (TTR); 4) the tourism destination regions (TDR); and 5) the tourism sector. However, for reasons that shall be explained as we proceed, our examination of the operations of Nigeria's inbound tourism and the place of foreign languages in it, on the basis of these elements of the tourism system, shall group together the elements of the tourist, the TTR, and the tourism sector.

\subsection{Nigeria's Inbound Tourism from a TGR Perspective: Foreign Languages as a Factor}

Cooper et al. (2008:7) have explained that it is the TGR that generates market for tourism 'and, in a sense, provides the 'push' to stimulate and motivate travel. It is from here that the tourist searches for information, makes the booking and departs". Statistics compiled by the United Nations World Tourism Organisation (UNWTO) for as recently as 2012 and 2013 have shown that, in a decreasing order of importance, China, the United States, Germany, the Russian Federation, the United Kingdom, France, Canada, Australia, Italy, and Brazil are the top ten spenders in international tourism (UNWTO Tourism Highlights, 2014: 13). 
This simply means that these are the top ten countries whose residents travel the most to other countries, which potentially include Nigeria.

If we were to base our study on these top ten TGR countries, the point to note is that a good part of the potential foreign tourist arrivals in Nigeria is not from English speaking countries among which Nigeria counts. Among these top ten TGR countries, only the U. S., the U. K., Australia, and Canada, speak English; and even Canada has a significant non English-speaking population. English has certainly come to acquire the status of the first language of international communication (cf. http://www.axl.cefan.ulaval.ca/Langues/2vital_inter_anglais.htm). But by no means does everybody in the world speak English. The actual population of speakers of the English language in the world (and this includes those who speak it as a mother tongue, as a second language, and as a foreign language), is said to be about 1.6 billion (cf. http://www.axl.cefan/ulaval.ca/Langues/2vital_inter_anglais.htm), out of a world population of over 7 billion persons as estimated by the United States Census Board and the United Nations Population Fund (en.wikipedia.org/wiki/World_population ). Since every potential foreign tourist arriving in Nigeria does not speak English, there is a place for foreign languages in the operations of Nigeria's inbound tourism.

From the point of view of actual foreign tourist arrivals in Nigeria, the United States Library of Congress Country Profile on Nigeria states in the paragraph on "Tourism" that in 2005, Nigeria received more than 2.7 million tourists and that of this number, the largest contingents came from Niger (620, 658), Bénin (303, 215), Liberia (107, 401) and Cameroon (107, 108)" (lcweb2.loc.gov/frd/cs/profiles/Nigeria.pdf). The above record reveals that Nigeria's actual foreign tourist arrivals come more from non English-speaking African countries, and specifically from Nigeria's French-speaking neighbours. This implies again that foreign languages are of some relevance in Nigeria's inbound tourism. For instance, unless they happen to also speak English, the tourists from the French-speaking countries of Niger Republic, Bénin Republic, and Cameroun, would need French-speaking tour guides to facilitate their stay and activities in Nigeria, if their visit to this country is to be worthwhile. 
If the world's largest TGR countries, which account for Nigeria's potential foreign tourist arrivals, and if countries representing Nigeria's actual foreign tourist arrivals, were both to be mostly English speaking, then foreign languages would not be such an important factor in Nigeria's inbound tourism operations and development. But as we have seen above, the largest potential and actual TGR countries for Nigeria's inbound tourism speak languages that are foreign to Nigeria. This naturally indicates that some action is necessary with respect to foreign languages in the operations of Nigeria's inbound tourism. This fact naturally leads us to an examination of these operations, to see what such actions are and the extent to which they have been taken. This implies an examination of the operations of Nigeria's inbound tourism from the perspective of Nigeria as a TDR.

\subsection{Nigeria's Inbound Tourism from a TDR Perspective: \\ The Foreign Languages Factor}

Nigeria's inbound tourism implies the Nigerian tourism industry considered from the perspective of Nigeria as a tourism destination, as a TDR country. It is that aspect of the Nigerian tourism industry that handles foreign tourists from their arrival in, to their departure from Nigeria. Examining the operations of Nigeria's inbound tourism with specific respect to the foreign languages factor, thus implies examining the foreign languages related actions in the Nigerian tourism industry from the perspective of Nigeria as a TDR country, those foreign languages related actions which are targeted at or which have a bearing on foreign tourists from their arrival in, to their departure from Nigeria.

The tourist destination region (TDR) is said to be the raison d'être for tourism, with a range of special places and activities, with cultural, historic, or natural significance. (see Cooper et al., 2008:7). Citing Leiper (1990:23), Cooper et al. continue as follows:

The 'pull' to visit destinations energises the whole tourism system and creates demand for travel in the generating region. It is therefore at the destination where the innovations in tourism take place - new products are developed and 'experiences' delivered making the destination the 'place where the most noticeable and dramatic consequences of the system occur' 
Cooper et al. infer that it is at the destination that the full impact of tourism is felt and planning and management strategies are implemented. From the particular perspective of a TDR country, inbound tourism operations therefore involve those actions, including planning and management strategies among many other things, which create demand in the TGR for travel to the TDR. And when this is viewed again from the particular perspective of the place of foreign languages in the inbound tourism operations of the TDR, attention is invariably drawn to foreign languages related actions in these operations which help to: 1) create demand in the TGR for travel to the TDR; and 2) plan for and manage the resultant foreign tourists arrivals and stay in, and departure from, the TDR. This section of our paper therefore has a two-fold business. One part of this is to examine Nigeria's inbound tourism operations in order to identify those foreign languages related actions that are capable of creating or facilitating demand for Nigeria as a tourism destination in the TGR, and to see the extent to which such actions have been taken. The other part is to examine Nigeria's inbound tourism operations with a view to identifying those foreign languages related actions which help to successfully manage or run the interests of foreign tourists in Nigeria, and to see the extent to which such actions have been taken.

\subsubsection{Foreign Languages and the Creation of Demand for Nigerian Tourism Destinations in the TGR}

It is a well known fact that language is a tool for communication. The section of this paper on foreign languages has also shown that foreign languages are, by their very definition, a tool for communication with foreigners. Foreign languages thus come into play whenever it has to do with matters of communicating with the TGRs with respect to Nigeria's inbound tourism. It is an obvious fact that potential tourists back home in their countries are not spirits to know about the various products (events, objects, places, experiences, etc.) that might interest them abroad. They need to be informed about these things. This is the very reason for tourism marketing actions and strategies of all kinds targeted at the TGR by the TDR. 
No less an authority on tourism operations around the world than the UNWTO has rated Nigeria's action rather poor in the business of disseminating information on Nigeria's tourism facilities in the TGR. The Nigeria Tourism Development Master Plan (2006), a document produced by the UNWTO at the request of the Government of Nigeria, and through the support of the United Nations Development Programme (UNDP), has remarked that on the score of Nigerian tourism generally,

The current marketing approach is very weak. The marketing of Nigeria as a tourist destination is underfunded and lacks a strategic marketing approach. The marketing collaterals are not up to international standards; while they are informative they are not customer friendly.

A survey of tour operators in the UK, Europe and the United States of America indicated a lack of information or knowledge about Nigeria as a tourist destination (Nigeria Tourism Development Master Plan, 2006: 5-6).

If general information on Nigeria as a tourism destination is scanty and actual marketing strategies on Nigeria as a tourism destination are poor in such English-speaking countries of the TGRs as the UK and the USA, then a worse situation must be expected in the non Englishspeaking countries. As Nigerian tourism stakeholders rise to respond to the criticisms formulated in the above citation from the Nigeria Tourism Development Master Plan (2006: 5-6), care must be taken to ensure that the measures put in place also cover the non Englishspeaking nations of the TGRs. The type of measures that may be put in place to improve upon the marketing of Nigeria's tourism destinations in the TGRs, and particularly in the non English-speaking nations, will shortly be addressed. But just before that is done, it is pertinent to examine the measures that have been taken so far, even as the UNWTO has found them inadequate as reported in the Nigeria Tourism Development Master Plan (2006).

The research for this paper has led us to a number of Nigerian tourism information products targeted at the TGRs. The first we shall mention here is the Nigerian Tourism Development Corporation (NTDC) website. The NTDC, by its enabling law, is the official tourism regulator in Nigeria. In this capacity, whatever information it gives out 
on Nigerian tourism is authoritative. And it has indeed posted much information on tourism in Nigeria on its website. Another information platform on Nigerian tourism is the websites of Nigerian foreign missions abroad, specifically those of the UK, the USA, Germany and some scanty information of the website of the Embassy in Russia. However, the much or little information on the foreign missions' websites are extracts or adaptations of what appears on the NTDC site. Regrettably, all the information on the NTDC and the foreign mission websites in in English, including the missions in the non Englishspeaking countries, as if everyone in the world speaks English. This has certainly confirmed the remark by UNWTO in the Nigeria Tourism Development Master Plan (2006) that there is a general lack of information in the TGRs on Nigeria as a tourism destination, and that whatever information there is, it is not customer friendly. In such important TGR countries like China, Russia, Germany, Brazil, France and other Frenchspeaking countries of Europe, and the Scandinavian countries, whatever information that is intended to attract tourists from these countries to Nigeria, and is expressed only in English is certainly not customer friendly. For one, it certainly gives out the impression that tourists to such a country will certainly face communication problems. Information given out in the tourists' languages, on the web, in printed brochures, that could be distributed by tourism desks at our embassies to travel agencies in those countries, could be more reassuring. It is reasonable to believe that foreign languages could be a useful tool in creating demand for Nigerian tourism destinations in the TGRs if carefully packaged information about these destinations is disseminated in the TGR countries in the languages of these countries. The NTDC has posted a considerable volume of information on Nigerian tourism destinations on its website. It should go a step further to repackage this information following international standards, update it regularly, and ensure good quality translation in the major languages of the world's active TGRs. The NTDC should also ensure the creation of tourism desks at our foreign missions abroad, which would in turn ensure the posting of comprehensive and up to date information on our missions' websites, as well as the production of printed brochures of such information, and all of this, in the languages of the countries where the missions are situated. 


\subsubsection{Foreign Languages and the Management of Foreign Tourists in Nigeria}

Our consideration of the TGR element of the tourism system with respect to the use of foreign languages in the development of tourism in Nigeria pointed us to the strategic use of these languages in the marketing of Nigerian tourism destinations in the TGRs of the world in order to attract a greater number of tourists to the country. We are now to consider the place of foreign languages in the management of the foreign tourists' visit to Nigeria. This can only mean the place of foreign languages in the functioning of the various aspects of the tourism industry in the country as they cater in their respective ways for the needs of the foreign tourists from their arrival in the country to their departure. This simply translates to the functioning of the tourists' activities and needs as an element of Leiper's tourism system, and the place of foreign languages in such functioning.

A simple way of examining the functioning of the management of tourists' activities and needs in its diverse domains with respect to the role of foreign languages in them is to identify the different aspects of the tourism industry with which a typical tourist is involved as $\mathrm{s} / \mathrm{he}$ arrives in the country, visits the destination(s), and departs from the country, with all the transactions and activities that go into making the tour successful and satisfactory, both for the tourist on the one hand, and for local tourism operators, on the other. Grosso modo, these aspects of the tourism industry include the following:

1) Transportation, which involves among others, the personnel of the travel agencies or tourism companies who may have to arrange to receive tourists at airports, train stations or motor stations and transport them away from there to their accommodation, as well as to and from the various places and events to be visited;

2) Hospitality, which involves hotel, hostel, camping, or any other type of accommodation, as well as catering services;

3) The wide variety of tourist attractions (places and events) which tourist(s) actually came to visit or which have been proposed to them;

4) The various other areas of human life and activity in which tourists have to transact one business or another in the course of their tour - financial institutions like the bank or the bureau de change where foreign tourists 
go for currency exchange transactions, health institutions in case of health challenges, diverse types of shopping facilities, etc.

In all these and in many others, foreign languages have a place: it has to do with the operators of certain areas of the Nigerian tourism industry communicating with the foreign tourists in the latter's languages, particularly if they are not able to speak English or speak it with difficulty. The most obviously concerned of these operators of the tourism industry are the personnel of travel agencies, of hotels (reception, bar, restaurant, and laundry staff), of tour operating agencies or companies (tour guides, etc.). Of particular importance are tour guides who often have to accompany foreign tourists on visits to tourist attractions, but who also have to help them arrange transportation, hotel accommodation, catering, currency transactions, medical consultations, shopping, purchase of souvenirs and mementos, etc. Foreign tourists are often excited and feel very much at home to find people who communicate with them in their native languages in a foreign land, and this adds to the thrill, success and satisfaction of the tour experience. This is then the rationale behind the practice in countries with a developed tourism industry, where foreign language skills are required from diverse categories of operators in the tourism sector. As a matter of fact, foreign language courses are quite often part of the curriculum for the training of several categories of manpower for the tourism industry in these countries. We may ask at this point what the present situation is regarding the level of foreign language proficiency of the personnel of the tourism industry in Nigeria generally. In our opinion, this question can only be answered by reference to the training that produces the personnel in question. And for this, we may consider the curriculum of the National Institute for Hospitality and Tourism (NIHOTOUR) which, by its claims on the "Welcome" page of its official website, is "the apex institution and professional ladder for the hospitality and tourism industry in Nigeria and the West Africa sub-region" (cf. www.nihotour.gov.ng), and for which reason it can be used as an index case here.

NIHOTOUR currently has seven campuses in the country, one campus in each of the geo-political zones of the country and in the Federal Capital Territory of Abuja. For the training of professional 
personnel for the Nigerian tourism industry, NIHOTOUR offers a wide range of study programmes under two Departments - the Department of Travel and Tourism Studies and the Department of Hospitality and Catering Services.

The Department of Travel and Tourism Studies offers the following programmes:

- Postgraduate Diploma in Tourism Management

- Diploma in Tourism and Recreation

- Diploma in Transport and Travel Management

- Diploma in Travel and Tourism Management

Professional Certificate programmes are also available in Tour Operations, Tour Guiding, Resort Development \& Management, Destination/Promotion, Small Scale Recreational Park and Garden Management, Travel Agency Operations, Event Operations and Management, and Tourism Journalism. The Department of Hospitality and Catering Services on its part, offers programmes for

- Postgraduate Diploma in Hospitality Management

- Diploma in Hospitality Management

- National Technical Certificate in Catering Craft Practice

- Certificate in Cookery and Pastry Practice

- Diploma in Food Hygiene

- Certificate in Food Hygiene

in addition to some other vocational skills development programmes leading to Professional Certificates in Hotel \& Catering Operations and Management, Fast Food Operations and Management, Food and Beverage Operations and Management, Night Club Operations and Management, Restaurant and Bar Operations and Management, Pastry and Confectionary, Culinary Skills (cf. www.nihotour.gov.ng/moreabout-joomla . Accessed on 30/03/2016 at 03:00).

Quite surprisingly, none of the above study programmes of the NIHOTUOR has any place for foreign language studies, except the Diploma in Tourism and Recreation programme which has two courses entitled French 1 and French 2. If we take this state of affairs in a professionally oriented tourism training institution to reflect the situation 
in the not so professionally minded institutions like the Polytechnics, where Tourism courses are also studied, we could conclude that foreign languages have not been given the attention they deserve in the training of tourism manpower in Nigeria.

Another place or role for foreign languages in the management of foreign tourists in Nigeria is to be found in what may be called here using foreign languages to make Nigerian tourism destinations more foreign tourist friendly by using these languages, beside English, in the writing of labels, descriptions, and abstracts of objects, places and events visited by the tourists, as well as the instructions on such objects, places, and events. The author has discovered on his recent personal visits to some tourist attractions across Nigeria (2013 2015), that at the sites where such descriptive literature exist at all (mostly in museums, at and on monuments, historical and cultural sites and objects), it is exclusively written in English. As earlier pointed out in this discussion, if English is the official language of the country, all tourists to the country do not, by any means, speak English, and all those who speak do not, by any means, speak it well enough to benefit usefully from the descriptive literature at and on these tourist sites, objects and events that are written in English. When this fact adds to the other fact that Nigerian tour guides rarely speak other languages of international communication than English, one can easily imagine what could be the frustration of any foreign tourist in Nigeria who does not speak English well. The frustration is all the more pronounced in comparison with the experience in other tourism destinations, particularly those in the developed world with an equally developed tourism industry, where descriptive literature at tourism sites is. usually written in many languages of international communication, and particularly those of the great tourists generating nations. This frustration, once experienced by tourists, could discourage a visit to other sites in the country and a repeat visit to the country. Reported back home in the tourist generating countries by those tourists who experienced it, such frustration holds great potentials to adversely affect international tourist arrivals in Nigeria, and thereby the growth of the country's inbound tourism in particular, and the whole of the country's tourism industry in general. 


\section{Conclusion}

Essentially, this discussion has attempted to draw the attention of stakeholders in the Nigerian tourism industry to the importance of foreign languages to the growth and development of the industry. Using Leiper's (1979) systems approach to the analysis of the tourism industry, this attempt has demonstrated this importance in several ways. One of them is that foreign languages are useful in, and in fact crucial to, the much desired optimal marketing of the Nigerian tourism destination in the largest tourists generating nations of the world through the dissemination of information on Nigerian tourism products in the languages of these nations, whose nationals, and particularly the potential tourists cannot, by any means, speak English, which is said to be fast becoming the first language of international communication. The discussion has suggested that such information dissemination could be done through tourism brochures and guides written in foreign languages and distributed to travel agencies and tourism organising companies in the foreign countries through the commerce and tourism offices that should be established in Nigerian diplomatic Missions abroad. It has also been suggested that the information on Nigerian tourism products disseminated online on the websites of Nigerian tourism enterprises from both the public and the private sector should also be done in other languages of international communication, and not only in English, as it is the case at present.

The above stated way of promoting the development of the tourism industry in Nigeria consists of marketing Nigeria as a tourism destination in the TGR, and ultimately translates to managing Nigeria' tourism image in the TGR. Two other ways of using foreign languages as a tool for the development of Nigeria's tourism industry as pointed out in this discussion belong to one and the same strategy - managing Nigeria as a TDR in a foreign tourist friendly manner. One of these two ways is to require competence in some foreign languages from some categories of personnel of the tourism industry, particularly those in the categories that make the most personal contacts with foreign tourists: personnel of travel agencies, tourism organizing companies, including tour guides in particular, bar, restaurant, and the reception desks of hotels, etc. The 
acquisition of this competence should also be provided for in the curriculum for the training of prospective tourism industry personnel in the relevant and specified categories. The discussion has attempted to show in what way this competence of these categories of personnel can enhance the satisfaction of our foreign tourists, and ultimately the growth of the industry.

The other of the two foreign tourist friendly ways of managing Nigerian tourism sites mentioned in the above paragraph consists of producing the literature used at these sites as labels, description of objects and places, abstracts, etc. in other languages of world communication besides English. Again, the body of this discussion has attempted to show in what way this measure can enhance the development and growth of Nigerian tourism.

On the whole, this discussion ends by submitting that by calling the attention of Nigerian tourism practitioners to the ways in which foreign languages can contribute to the growth and development of the Nigerian tourism industry, and particularly of its inbound dimension, it is also calling the attention of foreign language practitioners to ways that they can meaningfully contribute to the growth and development in Nigeria of this very important economic activity in the life of nations and of the world.

\section{References}

Achebe, C. (1975). "The African Writer and the English Language." Morning yet on Creation day. Ed. C. Achebe. London - Ibadan - Nairobi: Heinemann, 5562.

Adegbija, E. (2004). "The Domestication of English in Nigeria." The Domestication of English in Nigeria: A Festschrift in Honour of Abiodun Adetugbo. Eds. S. Awonusi, and E. A. Babalola. Lagos: University of Lagos Press. 20 44.

Alisah, B. F. (2005). "What is a Foreign Language?" Nigeria and the Foreign Language Question: A Book of Readings. Ed. T. Ajiboye. Ibadan: Caltop Publications (Nigeria) Limited. 10 - 30.

Bamiro, E. O. (1991). "Nigerian Englishes in Nigerian English Literature." World Englishes 10.1. 7 - 19.

Brann, C. M. B. (1981). "A Socio-Linguistic Typology of Language Contact in Nigeria: The Role of Translation” Babel 27.1. $9-12$. 
Chakraborty, A. and Chakravarti, B. A. (2008). Global Tourism. New Delhi: A. P. H. Publishing Corporation.

Cooper, C., Fletcher, J., Fyall, A., Gilbert, D. and Wanhill, S. (2008). Tourism Principles and Practice. ( $4^{\text {th }}$ Edition) Prentice Hall.

Crystal, D. (1972). Linguistics in Language Teaching. E. L. B. S. \& Arnold Brown, 1972.

Edung, M. T. U. (2001). "Foreign Language Studies and National Development in Nigeria: The Way Forward." IKO: A Journal of Languages, Arts and Social Sciences. 1. 1 - 26.

Frangialli, F. (2009). "From Tourism Statistics to the Tourism Satellite Account." Keynote, Session II: Integrating Tourism Statistics into a Broader Framework, Fifth UNWTO International Conference on Tourism Statistics. Bali, Indonesia: $30^{\text {th }}$ March $-2^{\text {nd }}$ April.

Gilbert, D. (1990). "Conceptual Issues in the Meaning of Tourism". Progress in Tourism, Recreation and Hospitality Management. Ed. C. Cooper. London: Belhaven Press, 1990. 4 - 27.

http://www.axl.cefan.ulaval.ca/Langues/2vital_inter_anglais.htm : Les langues du monde - La vitalité et la mort des langues - L'anglais, Accessed on 06/06/2014 at $08: 30$

Leiper, N. (1979). "The Framework of Tourism: Towards a Definition of Tourism, Tourist, and the Tourist Industry." Annals of Tourism Research 6.4. $390-407$.

National Institute for Hospitality and Tourism. www.nihotour.gov.ng

Novelli, M. (Ed.) (2005). Niche Tourism: Contemporary Issues, Trends and Cases. Elsevier Ltd.

United States Library of Congress. Country Profile - Nigeria. lcweb2.loc.gov/frd/cs/profiles/Nigeria.pdf (Accessed on 01/09/2016).

UNWTO. Glossary of Tourism Terms. UNWTO, 2014. (Accessed at http://s3-eu-west-

1.amazonaws.com/staticunwto/Statistics/Glossary+of+terms.pdf on 30/08/2016. Last updated, February 2014).

UNWTO. UNWTO Tourism Highlights. UNWTO, 2014. (Accessed at dtxtq4w60xqpw.cloudfront.net/sites/all/files/pdf/unwto_highlights14_en. pdf on 26/08/2016).

UNWTO. International Recommendations for Tourism Statistics, 2008. New York: United Nations, 2010. (Accessed at unstats.un.org/unsd/publication/ Seriesm/SeriesM_83rev1e.pdf\#page=21 on 30/08/2016). 
HSS, vol. VI, no. 2 (2017): 107-130

UNWTO. Nigeria Tourism Development Master Plan: Institutional Capacity Strengthening to the Tourism Sector in Nigeria. UNWTO, 2006. (Accessed at www.nacd.gov.ng/Tourism Master Plan.pdf on 05/09/2016).

Vanhove, N. Economic Characteristics of the Tourism Sector. V5.books.elsevier.com/bookscat/samples/9780750666374/9780750666374 .PDF, Accessed on 30/08/2016.

Wikipedia. World Population. en.wikipedia/org/wiki/World_population, Accessed on 30/08/2016.

Wilkins, D. A. (1972). Linguistics in Language Teaching. E. L. B. S. and Edward Arnold.

\section{Biographical note}

Mike Edung is currently a Senior Lecturer and teaches French Language courses in the Department of Foreign Languages, University of Uyo, Uyo, Akwa Ibom State, Nigeria. His major research interest and work in the last 10 - 12 years have focused on French for Specific Purposes, Terminology, Specialised Translation and Technical Writing, with particular application to Nigerian national development needs. He is currently working with a team of his postgraduate/research students on a bilingual (English/French) tourism brochure of Nigeria. 